\title{
Effects of stand density and seedlot on three wood properties of young radiata pine grown at a dry-land site in New Zealand
}

\author{
John R Moore ${ }^{1 *}$, Dave J Cown ${ }^{1}$, Russell B McKinley ${ }^{1}$ and Charles O Sabatia ${ }^{1,2}$
}

\begin{abstract}
Background: Manipulation of stand density and choice of genetic material are two key mechanisms through which forest managers can influence tree growth and wood properties. Past silvicultural practices in New Zealand have been characterised by early thinning to relatively wide spacing, while tree improvement programmes have primarily focussed on growth and form. The aim of this study was to quantify the impacts of stand density and past genetic selections on the wood properties of radiata pine (Pinus radiata D. Don).

Methods: Stress-wave velocity, wood density, microfibril angle (MFA) and modulus of elasticity (MOE) were measured on trees and wood samples taken from a 15-year-old silvicultural and tree breeds trial located in Canterbury, New Zealand. The focus of this study was comparison of seedlots with genetic ratings of GF6 and GF25. Data from pruned stands with final densities of 100, 200 and 400 stems ha $^{-1}$ were compared as were data from unpruned stands with stand densities of 200, 400, 600 and 1000 stems ha $^{-1}$.

Results: Stress-wave velocity of trees was affected by final stand density, with the lowest values recorded from trees in the 100 and 200 stems ha $^{-1}$ treatments. Values for wood MFA and MOE both showed the greatest amount of change when final stand density was less than 400 stems ha ${ }^{-1}$. Trees from the GF25-rated seedlot had wood density that was approximately $34 \mathrm{~kg} \mathrm{~m}^{-3}$ lower than trees from the GF6-rated seedlot.

Conclusion: Very high stand densities are not required in order to influence wood properties, but early thinning to low stand densities should be avoided. Such results are of practical importance to forestry managers.
\end{abstract}

Keywords: Silviculture; Genetics; Wood properties; Wood density; Microfibril angle; Modulus of elasticity

\section{Background}

Control of the growing space available to trees and the selection of planting stock with improved traits are two of the main processes through which forest managers can influence the growth and wood properties of trees within a stand (Savill and Sandels 1983; Smith et al. 1997). Spacing affects the vigour and characteristics of individual trees within a stand and also the total volume of wood obtained from a stand (Assmann 1970; Carson et al. 1999; Kilpatrick et al. 1981; Whyte and Woollons 1990). Trees grown in widely spaced stands are typically more tapered and have larger branches that remain alive further down the stem than trees growing more closely

\footnotetext{
* Correspondence: john.moore@scionresearch.com

'Scion, Private Bag 3020, Rotorua 3046, New Zealand

Full list of author information is available at the end of the article
}

together (Auty et al. 2012; Evert 1971; Hein et al. 2008; Maguire et al. 1991). Tree spacing can also affect a number of wood properties, such as density, microfibril angle (MFA) and stiffness (modulus of elasticity, MOE), that affect the performance of solid timber (Panshin and de Zeeuw 1980). Trees that are widely spaced (whether established at wide spacing or later thinned to a reduced stand density) generally have poorer wood properties than closely spaced trees (Macdonald and Hubert 2002).

Radiata pine (Pinus radiata D. Don) is the predominant commercial species grown in New Zealand (Ministry for Primary Industries 2012). Silvicultural regimes for this species are generally characterised by multiple thinning and pruning operations. Silviculture is driven by the primary goal of maximising profitability and this led to the development of regimes based on wide tree 
spacing and heavy early thinning from the 1960s to the 1990s (James 1990). In the most extreme cases, the residual stand densities following final thinning were as low as 200 trees $\mathrm{ha}^{-1}$. The rationale used during that period was that the best financial return came from growing large pruned logs (Fenton and Sutton 1968). Silvicultural regimes developed more recently do not generally involve such low stocking rates but are, nevertheless, still based on the desire to maximise profitability. Given that rotation lengths are generally around 30 years, trees will contain a relatively high proportion of corewood, which generally has poorer wood properties than outerwood (Burdon et al. 2004; Zobel and Sprague 1998).

Many wood properties are also under a moderate to high degree of genetic control, but these were often considered secondary traits in tree improvement programmes. Breeding programmes have instead focussed on improving growth, form and tolerance of a wide range of site conditions (Zobel and Jett 1995). However, competition from alternative materials has increased in recent years so the performance characteristics of wood products must continue to meet end-user expectations and requirements otherwise market share is likely to be lost (Roos et al. 2010; Vinden 2003). These economic drivers have led to an increased focus on: (a) breeding trees for improved wood quality; (b) non-destructive evaluation of wood properties (e.g. measuring tree stiffness using portable acoustic tools (Kumar 2004; Kumar and Burdon 2010; Kumar et al. 2006)); and (c) understanding the impact of past genetic selections on wood quality given that many desirable growth and wood quality traits are adversely correlated (Gapare et al. 2009; Kumar et al. 2008).

New Zealand also has a long history of tree breeding dating back to the 1950s when the first plus tree selections were made (Burdon 2008; Carson 1996; Jayawickrama and Carson 2000). The long-standing goal of various radiata-pine breeding programmes has been the rapid growth of large, well-formed trees, which has given rise to the Growth and Form (GF) breed (Jayawickrama and Carson 2000). Different selections of plus trees have been made within this breed; the main ones being the 850,268 and 870 Series. The 850 Series was an early selection based on the results of an intensive search of radiata pine stands across New Zealand for trees with better-than-average growth, good stem form and light branching. The 268 Series was obtained from trees in the northern part of Kaingaroa Forest (latitude $38^{\circ} 41^{\prime} \mathrm{S}$, longitude $176^{\circ} 34^{\prime} \mathrm{E}$ ). The forest was divided into onehectare blocks then the best tree in each block was identified and selected using the same criteria as for the 850 Series. The 870 Series was obtained by selecting trees from throughout New Zealand with long internodes, combined with good growth and stem form (Carson 1996; Jayawickrama et al. 1997). Numerous different seedlots have been produced within each series, initially through open pollination and more latterly through controlled pollination. Each seedlot is assigned a rating based on the breeding values for growth and form (GF), in which growth is given twice the weighting as form. This rating gives a strong indication of genetic worth (Vincent 1987).

A set of trials was established between 1987 and 1991 at 28 locations throughout New Zealand to compare the performance of these genetically improved breeds when grown at a range of stocking levels. This set of trials was designed to include all eight major forest growing regions. Up to four levels of site quality were tested within each region and each trial installation typically included five different stand densities. The trials are intended to run for an entire rotation, i.e. around 30 years. Early growth and yield results from those trials installed in 1987 were reported by Carson et al. (1999). One of the 1991 trials was located at Shellocks Forest, $40 \mathrm{~km}$ south of Christchurch. This trial contained five seedlots - two from the 268 Series, one from the 850 Series, one from the 870 Series plus one from an early "climbing select" series (i.e. mild mass selection from climbing trees in 16-20 year old stands). Unfortunately, the site of this trial was sold for conversion into farmland and the forest scheduled for harvesting in 2005 when the trees were only 15 years old. Although premature removal of this trial prevents the collection of 30-year data as intended and cross-comparison with other sites, this situation did provide an opportunity to examine the effects of stand density, pruning and genetic selection on various wood properties at a younger age. Thus, the aim of this study became to collect and analyse data on three wood properties (wood density, microfibril angle and modulus elasticity) from the 15-year-old trees felled at the Shellocks Forest site. The results reported here are a specific subset of the total data collected.

\section{Methods}

\section{Site}

The trial was established in 1991 at Shellocks Forest, Dunsandel on the Canterbury Plains, $40 \mathrm{~km}$ south of Christchurch, New Zealand (latitude $43^{\circ} 40^{\prime} \mathrm{S}$, longitude $172^{\circ} 11^{\prime} \mathrm{E}$, elevation $115 \mathrm{~m}$ a.s.l.). Soil at the site is free draining, of low fertility and is classified as Pallic Firm Brown soil belonging to the Lismore series (Hewitt 1998). Long-term average annual rainfall at the closest meteorological station to the site (Christchurch Airport) is approximately $630 \mathrm{~mm}$ (New Zealand Meteorological Service 1983) and seasonal water deficits are common (Watson et al. 2004; Watt et al. 2003). 


\section{Trial design}

The experiment was designed to investigate the effects of seedlot, stand density and pruning on growth and wood properties. It contained five different radiata pine seedlots, four levels of post-thinning stand density (100,

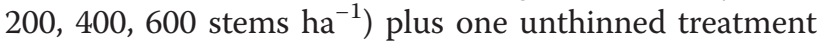
(1000 stems ha ${ }^{-1}$ ), and two levels of pruning (pruned or unpruned). Only 25 of the 50 possible factorial combinations of seedlot, stand density and pruning were actually included in the original experiment (Table 1). Furthermore, there was only a single replicate of each selected treatment combination, so that the experiment consisted of 25 plots, each assigned a different treatment combination. These plots were $45 \mathrm{~m} \times 36 \mathrm{~m}$ in size except in the treatment combinations associated with the lowest level of stand density (100 stems ha ${ }^{-1}$ ) where plot size was $45 \mathrm{~m} \times 72 \mathrm{~m}$.

\section{Seedlots}

Five radiata pine seedlots were used (88/201, 90/294, 88/ $105,89 / 15$ and 88/102). The origin and GF rating of each seedlot are given in Table 2. The seedlots will be referred to by their GF rating from here on for clarity. None of the seedlots were bred for improved wood properties.

\section{Silvicultural treatments}

Plots in the experiment were established at three levels of initial stand density (250, 500 and 1000 stems ha ${ }^{-1}$ ). Thinning was carried out in 1999 when the mean stand height was $7.1 \mathrm{~m}$ and the trees were eight years old. The GF6-, GF13- and GF25-rated seedlots were planted at each combination of initial stand density and thinned to each final level of stand density as follows. All the plots established at 250 stems ha $^{-1}$ or 500 stems ha $^{-1}$ were thinned using a thinning ratio (ratio of initial stand density to post-thinning stand density) of $2.5: 1$. This ratio was also applied to a proportion of the 1000 stems

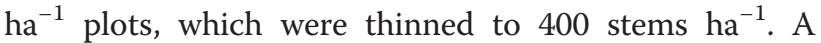
thinning ratio of 1.7:1 was applied to another proportion of 1000 stems ha ${ }^{-1}$ plots to obtain a final stand density of 600 stems $\mathrm{ha}^{-1}$. This resulted in four levels of postthinning stand density (100, 200, 400, 600 stems ha $\left.{ }^{-1}\right)$. The remainder of the 1000 stems ha ${ }^{-1}$ plots were left unthinned (thinning ratio of 1:1). The GF14- and GF16rated seedlots were each planted at only two initial stand densities (500 and 1000 stems ha ${ }^{-1}$ ). In each case, all the 500 stems ha $^{-1}$ plots were thinned to 200 stems ha $^{-1}$ while all the 1000 stems ha $^{-1}$ plots were unthinned (Table 1).

Pruning was also carried out in 1999 when the mean stand height was $7.1 \mathrm{~m}$ and the trees were eight years old. Trees in 11 of the 25 plots were pruned (P) to leave an average of $4.2 \mathrm{~m}$ of green crown remaining; this corresponded to a mean pruned height of approximately 2.7 $\mathrm{m}$. Trees in the remaining 14 plots were unpruned (UP) (Table 1).

\section{Data collection \\ Field measurements}

In the time between planting and data collection, it had been discovered that seedlot 89/15 from the longinternode 870 Series produced trees with poor stem form. Consequently, there was a lack of market acceptance for this seed, and it is not commonly planted commercially (Burdon, 2008). Therefore, no data were collected from trees in the seven plots planted with this seedlot. In each of the remaining 18 plots, 15 trees with good stem form were selected from across the diameter range (270 trees in total) and their diameter at a breast height of $1.4 \mathrm{~m}(\mathrm{DBH})$ and total height $(\mathrm{H})$ were measured. Stress-wave (acoustic) velocity measurements were made on each tree using two different standingtree tools: an IML Hammer (Instrumenta Mechanic Labor GmbH, Wiesloch, Germany), and a ST-300 (Fibre-gen, Christchurch, New Zealand). Two sets of

Table 1 Trial design for the silviculture and tree breeds trial located at Shellocks Forest

\begin{tabular}{|c|c|c|c|c|c|c|c|c|c|}
\hline \multicolumn{5}{|c|}{ Silviculture } & \multicolumn{5}{|c|}{ Seedlot rating } \\
\hline \multirow[t]{2}{*}{ Trt. } & \multirow[t]{2}{*}{ Pruning } & \multicolumn{2}{|c|}{ Stand density (stems ha ${ }^{-1}$ ) } & \multirow[t]{2}{*}{ Thinning ratio } & \multirow[t]{2}{*}{ GF6 } & \multirow[t]{2}{*}{ GF14 } & \multirow[t]{2}{*}{ GF16 } & \multirow[t]{2}{*}{ GF25 } & \multirow[t]{2}{*}{ GF13 } \\
\hline & & Initial & Final & & & & & & \\
\hline 1 & $P$ & 250 & 100 & $2.5: 1$ & $x^{1}$ & & & $x$ & $x$ \\
\hline 2 & $P$ & 500 & 200 & $2.5: 1$ & $x$ & $x$ & $x$ & $x$ & $x$ \\
\hline 3 & $P$ & 1000 & 400 & $2.5: 1$ & $x$ & & & $x$ & $x$ \\
\hline 4 & UP & 500 & 200 & $2.5: 1$ & $x$ & & & $x$ & $x$ \\
\hline 5 & UP & 1000 & 400 & $2.5: 1$ & $x$ & & & $x$ & $x$ \\
\hline 6 & UP & 1000 & 600 & $1.7: 1$ & $x$ & & & $x$ & $x$ \\
\hline 7 & UP & 1000 & 1000 & $1: 1$ & $x$ & $x$ & $x$ & $x$ & $x$ \\
\hline
\end{tabular}

Each of the 25 treatment combination present in the trial is indicated by an " $x$ ". None of the GF13 seedlot material was sampled in the current study. 
Table 2 Description of the seedlots planted in the experiment

\begin{tabular}{llll}
\hline Breeding series & Seedlot number & Seedlot rating & Description \\
\hline "268 series" & $88 / 201$ & GF16 & Open-pollinated seedlot from the Brightwater seed orchard \\
"268 series" & $90 / 294$ & GF25 & Control-pollinated mix from the top 16 clones in the "268 series" \\
"850 series" & $88 / 105$ & GF14 & Open-pollinated mix of plus trees from Gwavas, Kaingaroa and Waimihia forests \\
"870 series" & $89 / 15$ & GF13 (LI25) & Open-pollinated mix from seven long-internode clones \\
"climbing select" & $88 / 102$ & GF6 & Climbing select from Kaingaroa and Rotoehu forests \\
\hline
\end{tabular}

measurements were made with each instrument; one on the north and one on the south side of each tree. These measurements were centred about breast height and the probes of the instruments were spaced approximately $1 \mathrm{~m}$ apart along the longitudinal axis of the stem. The acoustic velocity value for a treatment plot was computed as the arithmetic mean of the acoustic velocity measurements from the 15 sample trees in the plot.

The trees were felled once these measurements had been completed. The resulting logs were initially crosscut at the point where the stem diameter was $10 \mathrm{~cm}$. The length of this stem section was typically 9-12 m, but was shorter in some cases where the stem was forked. The stress-wave velocity was measured on this stem section using the HM-200 tool (Fibre-gen, New Zealand). A disc $50 \mathrm{~mm}$ in thickness was then cut out at the breast height position on the log to provide samples for measuring ring-level wood properties.

\section{Wood property measurements}

Ten discs were selected at random from the 15 discs obtained from each plot. Wood samples measuring $15 \mathrm{~mm}$ in both the tangential and longitudinal directions were taken from the pith to the cambium on the north side of the disc. Regions containing compression wood and/or knots were avoided. These samples were soaked in ethanol to prevent fungal decay and to minimise fibre collapse; four ethanol exchanges were carried out, each lasting 48 hours. From each sample a strip spanning the full radius of the tree was milled using a twin-blade sawing system. Each strip had dimensions of $7 \mathrm{~mm}$ in the longitudinal direction and $2 \mathrm{~mm}$ in the tangential direction, and was prepared in accordance with the requirements for the SilviScan system (Evans 1999). All strips were extracted with boiling acetone using Soxhlet apparatus to remove resins present in the wood that could affect subsequent measurements. Strips were then conditioned at $40 \% \mathrm{RH}$ and $20^{\circ} \mathrm{C}$ in a climate-controlled room to reach an equilibrium moisture content of $7-8 \%$.

Radial profiles of MFA were determined for each strip from the standard deviation of the 002 azimuthal diffraction pattern using the SilviScan-2 instrument (Evans 1999; Evans et al. 1999) located at CSIRO, Melbourne, Australia. X-ray diffraction measurements were made at $50 \mu \mathrm{m}$ resolution and the average MFA was determined over successive $5 \mathrm{~mm}$ intervals. X-ray densitometry measurements were made on each strip at a resolution of 50 $\mu \mathrm{m}$ in order to identify annual growth rings. Ring-level average values of wood density and MFA were calculated from the radial profiles, and these were used to estimate MOE using the approach described in Evans and Ilic (2001).

\section{Data analysis}

The current investigation focused on two components of the trial (Table 1) that formed complete two-way factorial experiments. The two components were: 1) a 3 by 2 stand-density by seedlot experiment for pruned stands with final densities of 100, 200 and 400 stems ha $^{-1}$ containing trees from seedlots with genetic ratings of GF6 and GF25, hereinafter referred to as the pruned experiment; and 2) a 4 by 2 stand-density by seedlot experiment in unpruned stands with final densities of 200, 400, 600 and 1000 stems ha $^{-1}$ containing trees from seedlots with genetic ratings of GF6 and GF25, hereinafter referred to as the unpruned experiment. The two experiments were analysed separately.

\section{Tree-level acoustic velocity}

There was just a single mean value of acoustic velocity per treatment combination (Tables 3 and 4), so data from the pruned and unpruned experiments were subjected separately to simple two-way comparison analysis. Prior to analysis, the data were tested for stand-density by seedlot interaction using Tukey's single-degree-offreedom test for non-additivity (Milliken and Johnson 1989; Tukey 1949) using the GLM procedure in SAS software (SAS Institute Inc. 2004-2009). There was no evidence to show there was a seedlot by stand density interaction in tree-level acoustic velocity in either the pruned or unpruned experiments $(p \geq 0.1359$ and $p \geq$ 0.0948 , respectively). For this reason, the analysis of tree-level acoustic velocity data was based on the main effects of stand density and seedlot. The seedlot by stand density interaction was used to provide an estimate of experimental error (analogous to the case of a randomised complete block design with fixed blocks). The following statistical model was used:

$$
y_{i j}=\mu+S_{i}+G_{j}+\varepsilon_{i j}
$$


Table 3 Average plot-level acoustic-velocity measurements for treatment combinations in the pruned experiment

\begin{tabular}{|c|c|c|c|c|}
\hline \multirow{2}{*}{$\begin{array}{l}\text { Acoustic } \\
\text { velocity } \\
\text { tool }\end{array}$} & \multirow{2}{*}{$\begin{array}{l}\text { Seedlot } \\
\text { genetic } \\
\text { rating }\end{array}$} & \multicolumn{3}{|c|}{ Acoustic velocity $\left(\mathrm{km} \mathrm{s}^{-1}\right)$ at final stand density } \\
\hline & & 100 & $200\left(\right.$ stems ha ${ }^{-1}$ ) & 400 \\
\hline \multirow[t]{2}{*}{ ST-300 } & GF6 & 2.434 & 2.743 & 3.065 \\
\hline & GF25 & 2.461 & 2.755 & 3.125 \\
\hline \multirow[t]{2}{*}{ IML hammer } & GF6 & 1.903 & 2.094 & 2.316 \\
\hline & GF25 & 1.899 & 2.101 & 2.356 \\
\hline \multirow[t]{2}{*}{ HM-200 } & GF6 & 1.848 & 2.098 & 2.345 \\
\hline & GF25 & 1.918 & 2.081 & 2.385 \\
\hline
\end{tabular}

where $y_{i j}$ is the average acoustic velocity measurement for the $i^{\text {th }}$ level of stand density and the $j^{\text {th }}$ seedlot, $\mu$ is the overall mean, $S_{i}$ is the fixed effect of the $i^{\text {th }}$ level of stand density $(i=100,200,400$ for the pruned experiment and $i=200,400,600,1000$ for the unpruned experiment), $G_{j}$ is the fixed effect of seedlot with the $j^{\text {th }}$ genetic rating $(j=\mathrm{GF} 6, \mathrm{GF} 25)$, and $\varepsilon_{i j}$ is a random error associated with the $j^{\text {th }}$ genetic rating plot under the $i^{\text {th }}$ stand density $\left(\varepsilon_{i j} \sim N\left(0, \sigma_{\varepsilon}^{2}\right)\right)$. The statistical model in Equation 1 was fitted using the GLM procedure in SAS software (SAS Institute Inc. 2004-2009). Multiple comparisons between the factor-level means were made using the Tukey honest significant difference (HSD) adjustment of comparison-wise $p$-values to maintain an experiment-wise cut-off $p$-value of 0.05 .

\section{Ring-level MFA, MOE and wood density}

The radial trends in wood density, MFA and MOE were modelled using a power function of the form:

$$
Y=\alpha X^{\beta}
$$

where $Y$ is the MFA, MOE or wood density, $X$ is the ring number with the ring closest to the pith designated as ring number 1 , and $\alpha$ and $\beta$ are parameters to be estimated from the data. The parameter $\alpha$ is the value of the response variable for ring number 1 and $\beta$ is a measure of the radial rate of change of the response variable. Each treatment combination in both the pruned and unpruned experiments was considered to be a separate group and was analysed separately using the following model:

$$
Y_{i j k l}=\left(\alpha_{i j}+\mathrm{a}_{i j k}\right) R_{i j k l}^{\left(\beta_{i j}+\mathrm{b}_{i j k}\right)}+\varepsilon_{i j k l}
$$

where $Y_{i j k l}$ is the breast height MFA, MOE or wood density of the $l^{\text {th }}$ ring $\left(R_{i j k l}\right)$ in the $k^{\text {th }}$ tree in the $i^{\text {th }}$ stand density by $j^{\text {th }}$ seedlot treatment combination; $\alpha_{i j}$ is the pith ring MFA, MOE or wood density parameter, and $\beta_{i j}$ is the radial rate of change parameter for these responses, in the $i^{\text {th }}$ stand density by $j^{\text {th }}$ seedlot treatment combination; $\mathrm{a}_{i j k}$ and $\mathrm{b}_{i j k}$ are random effects of the $k^{\text {th }}$ tree in the $i^{\text {th }}$ stand density by $j^{\text {th }}$ seedlot treatment combination $\left(\mathrm{a}_{i j k} \sim N\left(0, \sigma_{\mathrm{a}_{i j}}^{2}\right), \mathrm{b}_{i j k} \sim N\left(0, \sigma_{\mathrm{b}_{i j}}^{2}\right)\right)$; and $\varepsilon_{i j k l}$ is a zero expectation random error due to the $l^{\text {th }}$ ring in the $k^{\text {th }}$ tree in the $i^{\text {th }}$ stand density by $j^{\text {th }}$ seedlot treatment combination. The residuals from fitting the data to Equation 3 exhibited heteroscedasticity so this was modelled (separately for each treatment combination) as a power function of the predicted value of $Y_{i j k l}$ at the given $R_{i j k l}$. Correlations among the errors $\varepsilon_{i j k l}$ for rings within the same tree were not modelled as these were considered to have been accounted for by the random effect parameters $\mathrm{a}_{i j k}$ and $\mathrm{b}_{i j k}$. The size of the model residuals was reduced and the estimates of the variance of the random effect parameters became negligible when the random effect and correlation parameters were simultaneously included in Equation 3. The the 'nlme' package (Pinheiro et al. 2013) in the $\mathrm{R}$ software package ( $\mathrm{R}$ Development Core Team 2014) was used for computation.

\begin{tabular}{|c|c|c|c|c|c|}
\hline \multirow{2}{*}{$\begin{array}{l}\text { Acoustic } \\
\text { velocity } \\
\text { tool }\end{array}$} & \multirow{2}{*}{$\begin{array}{l}\text { Seedlot } \\
\text { genetic } \\
\text { rating }\end{array}$} & \multicolumn{4}{|c|}{ Acoustic velocity $\left(\mathrm{km} \mathrm{s}^{-1}\right)$ at final stand density } \\
\hline & & 200 & 400 (stems ha ${ }^{-1}$ ) & 600 & 1000 \\
\hline \multirow[t]{2}{*}{ ST-300 } & GF6 & 2.577 & 2.963 & 2.907 & 2.832 \\
\hline & GF25 & 2.624 & 2.955 & 2.807 & 2.831 \\
\hline \multirow[t]{2}{*}{ IML hammer } & GF6 & 1.891 & 2.186 & 2.183 & 2.130 \\
\hline & GF25 & 1.966 & 2.124 & 2.075 & 2.105 \\
\hline \multirow[t]{2}{*}{ HM-200 } & GF6 & 2.008 & 2.305 & 2.364 & 2.332 \\
\hline & GF25 & 1.994 & 2.254 & 2.223 & 2.349 \\
\hline
\end{tabular}

Table 4 Average plot-level acoustic-velocity measurements for treatment combinations in the unpruned experiment 


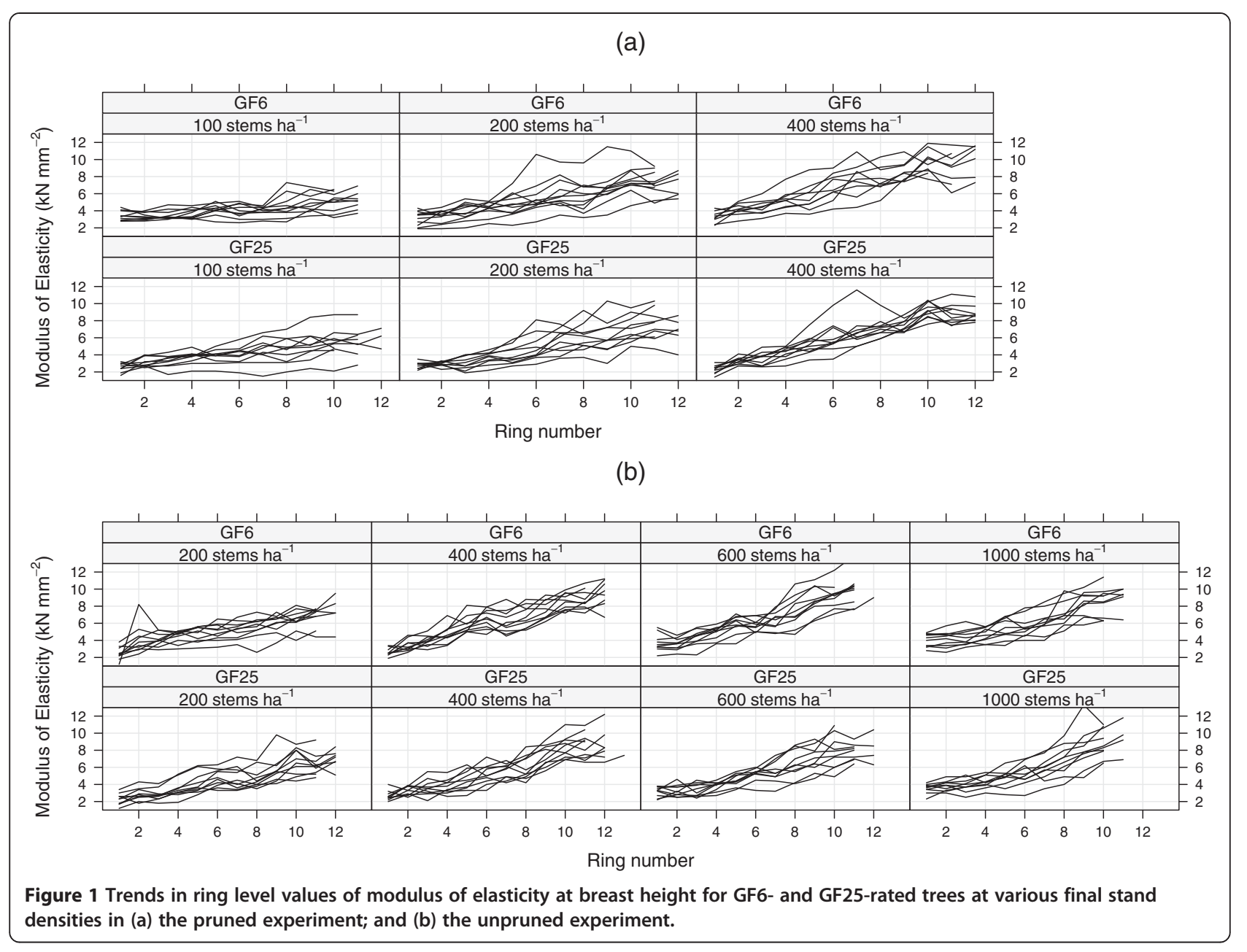

One GF25-rated tree in the pruned 400 stems ha ${ }^{-1}$ plot exhibited an unusual MOE trend (Figure 1a) and one GF6-rated tree from the unpruned 200 stems ha ${ }^{-1}$ plot exhibited an unusually high density for the first two rings (Figure 2b) so data from these two trees were excluded from the model. The effects of genetic rating and final stand density on breast-height ring-level MFA, MOE and wood density were inferred from comparison of the $95 \%$ confidence intervals of the parameter estimates of $\alpha_{i j}$ and $\beta_{i j}$ across the stand-density and seedlot treatments. Equation 3 was also used to calculate the expected values of MFA, MOE and wood density for the ring 15 from the pith, which corresponded to the age of the trees when felled.

\section{Results}

\section{Tree dimensions}

Differences in tree height, $\mathrm{DBH}$ and height:DBH ratio were not formally compared between treatments using tests of significance, but mean values and general trends are reported to aid in interpreting the influence of treatment factors on wood properties. The higher the final stand density, the lower the DBH for unpruned trees of either seedlot examined. A similar trend was also observed in most cases for pruned trees (Figure 3). The height of unpruned GF6-rated trees grown at a final stand density of 400 stems $\mathrm{ha}^{-1}$ was almost approximately $2 \mathrm{~m}$ greater than those at a final stand density of 200 stems ha ${ }^{-1}$, but higher final stand densities resulted in a reduction in tree height. Similar, but less pronounced, differences were observed for the unpruned GF25-rated seedlot and for pruned trees from both seedlots (Figure 3). The ratios of height to DBH were greater for trees grown at higher final stand densities, irrespective of seedlot or pruning treatment (Figure 3).

\section{Tree-level acoustic velocity}

Average tree-level acoustic-velocity measurements for the two-way factorial experiments for pruned and unpruned trees are given in Tables 3 and 4, respectively. 


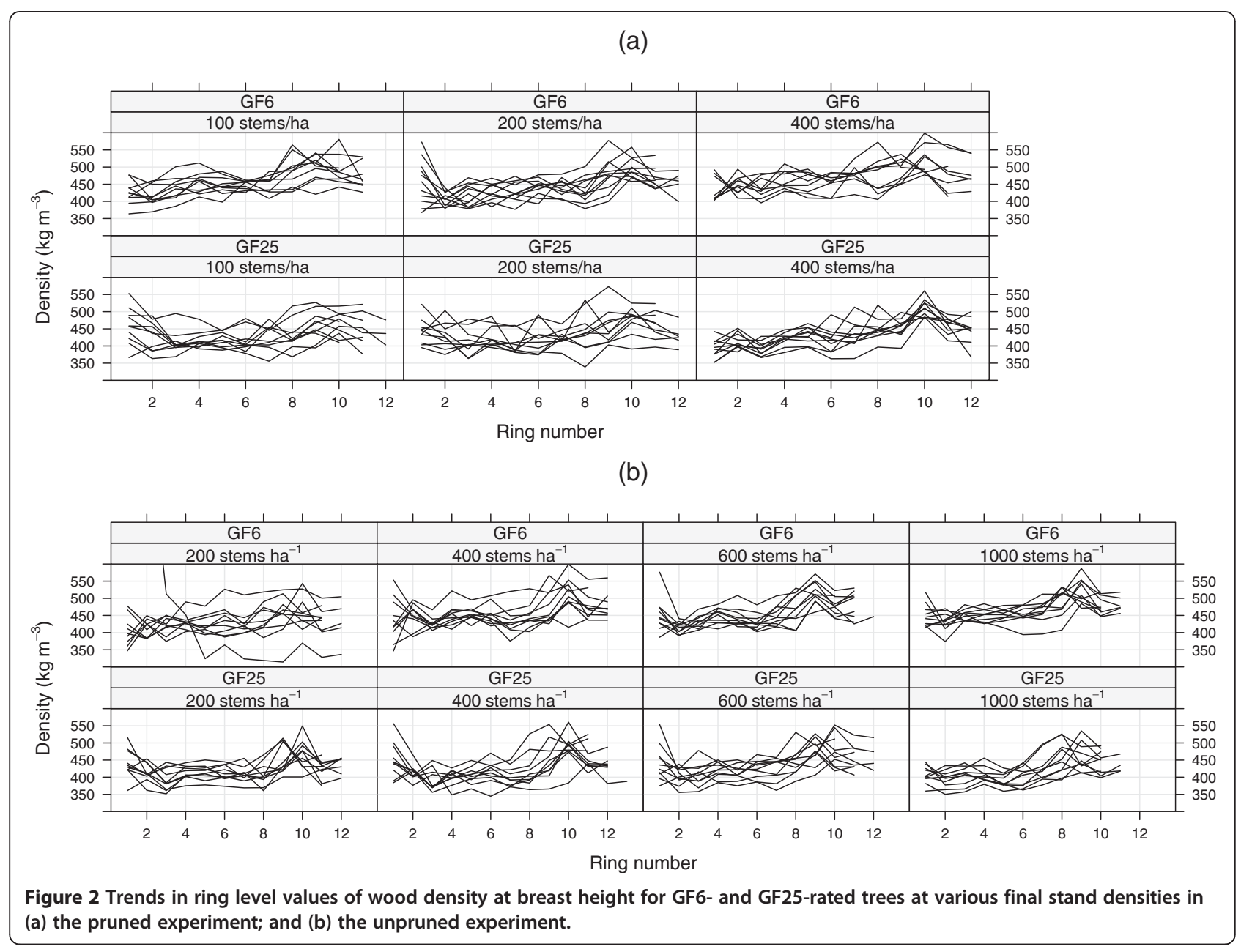

Analysis of variance using the linear statistical model given in Equation 1 showed that final stand density had a significant effect on the acoustic velocity of trees in both the pruned and unpruned experiments. These results were irrespective of the type of tool used with the exception of the unpruned experiment measured using the IML hammer (Table 4). No significant differences in acoustic velocity were found between seedlots in either the pruned or the unpruned experiment, irrespective of the type of tool used. The test statistics and associated $p$-values for the overall analysis of variance in the two experiments are given in Table 5.

Marginal mean values of acoustic velocity across the range of final stand densities and between seedlots with different genetic ratings are compared in Table 6 for the two experiments. The effect of stand density was significant for mean acoustic velocity values (irrespective of the measurement tool used) from the pruned experiment (adjusted $p \leq$ 0.0401). Results from the unpruned experiment were less clear cut. Mean acoustic velocity for trees in the 200 stems $\mathrm{ha}^{-1}$ treatment was significantly lower (adjusted $p \leq 0.0386$ ) than at the other final stand densities when measured using the ST-300 or HM-200 tools but not for the IML hammer. The mean acoustic velocities for trees grown at the other three final stand densities tested (400, 600 and 1000 stems $\mathrm{ha}^{-1}$ ) were not significantly different from one another (adjusted $p \geq 0.1683$ ). For acoustic velocity values measured using the IML hammer, the mean acoustic velocity from trees across all four final stand densities in the unpruned experiment were not significantly different from each other (adjusted $p \geq 0.0757$ ).

\section{Ring-level microfibril angle}

Trends in the breast-height ring-level values of MFA are shown for each individual tree in Figures 4, 1 and 2, respectively. Neither the pith-ring MFA (parameter $\alpha_{i j}$ ) nor the radial rate of change in MFA (parameter $\beta_{i j}$ ) differed between the seedlots tested for a given final stand density in either the pruned or the unpruned experiment (Figure 5). The only exception was in the 200 stems ha $^{-1}$ treatment in the unpruned experiment where the pith ring MFA in GF25-rated trees was higher than that in GF6-rated trees, while the radial rate of change in MFA for the GF25-rated trees was slower than that of the 


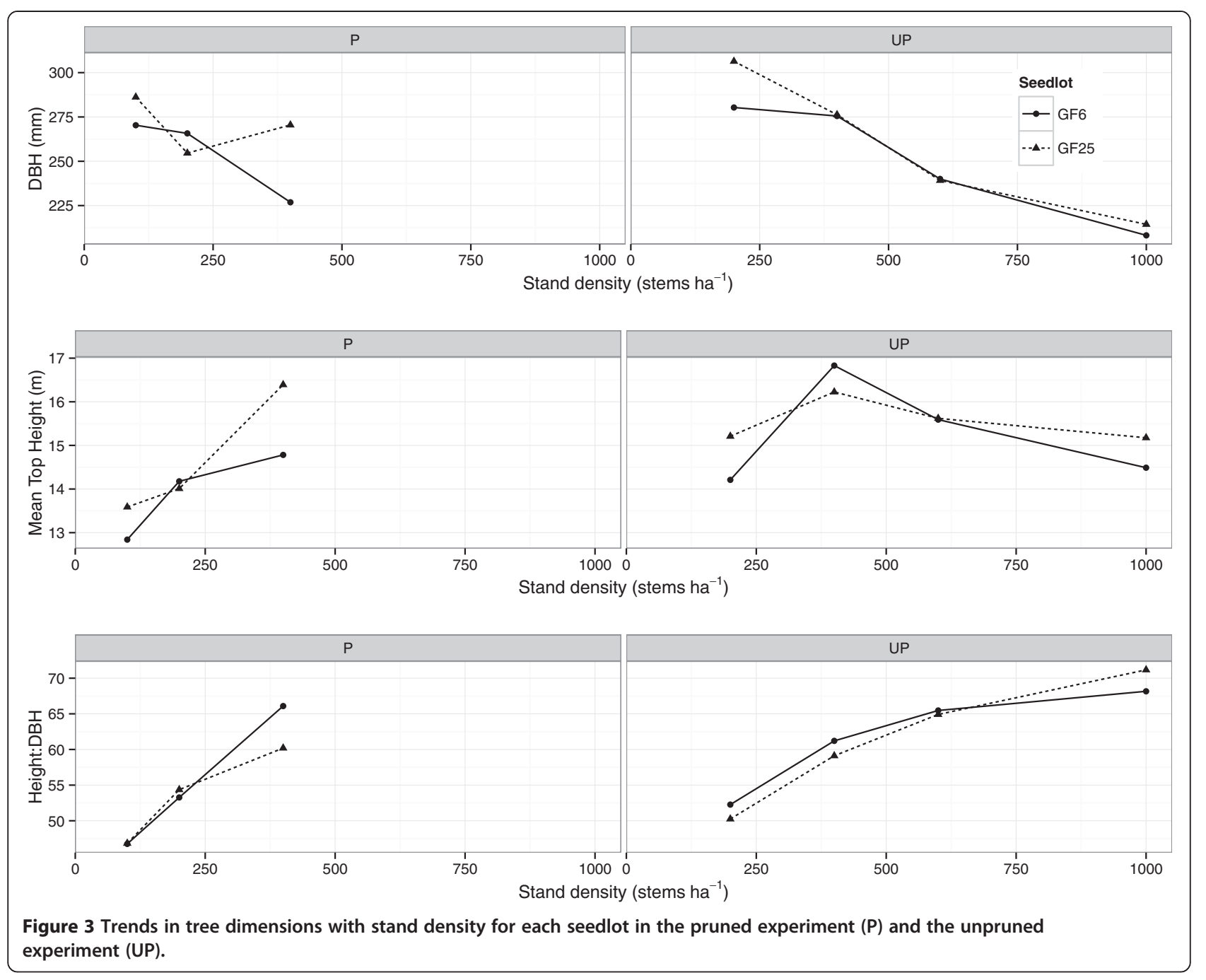

GF6-rated trees. As expected, the radial rate of change in MFA was negative indicating a decrease in MFA the further away the ring is from the pith in all the treatment combinations across both the pruned and unpruned experiments.

In the pruned experiment, pith-ring MFA (parameter $\left.\alpha_{i j}\right)$ was significantly higher $(p<0.05)$ in GF6-rated trees grown at a final stand density of 200 stems ha ${ }^{-1}$ compared with those grown at a final stand density of 100 stems ha ${ }^{-1}$ but did not change at higher final stand densities (Figure 5a). No statistically significant differences were found for trees from the GF25-rated seedlot. Radial rate of decrease in MFA was slowest in trees grown at a final stand density of 100 stems ha $^{-1}$ and fastest in trees

Table 5 Analysis of variance values of the F-test statistics and associated probability $>F(p)$ values for the effects of the stocking and genetic rating factors on acoustic velocity in the pruned and unpruned experiments

\begin{tabular}{|c|c|c|c|c|c|c|c|}
\hline \multirow[t]{3}{*}{ Factor } & \multirow[t]{3}{*}{ Test statistic } & \multicolumn{6}{|c|}{ Experiment and type of tool used } \\
\hline & & \multicolumn{3}{|c|}{ Pruned } & \multicolumn{3}{|c|}{ Unpruned } \\
\hline & & ST-300 & IML hammer & $\mathrm{HM}-200$ & ST-300 & IML hammer & HM-200 \\
\hline \multirow[t]{2}{*}{ Final stand density (stems ha ${ }^{-1}$ ) } & $F_{\text {ndf,ddf }}$ & 863.61 & 351.88 & 120.49 & 24.27 & 7.12 & 20.12 \\
\hline & $p$-value & $0.001^{*}$ & $0.003^{*}$ & $0.008^{*}$ & $0.013^{*}$ & 0.071 & $0.017^{*}$ \\
\hline \multirow[t]{2}{*}{ Genetic rating } & $F_{\text {ndf,ddf }}$ & 6.19 & 1.10 & 1.46 & 0.26 & 0.59 & 1.90 \\
\hline & $p$-value & 0.131 & 0.404 & 0.350 & 0.645 & 0.498 & 0.262 \\
\hline
\end{tabular}

Note: For the stand density, $F_{n d f, d d f}=F_{2,2}$ for the pruned experiment and $F_{n d f, d d f}=F_{3,3}$ for the unpruned experiment. For the genetic-rating factor, the test statistics are $F_{1,2}$ and $F_{1,3}$ for the two experiments respectively.

*denotes significance at $p<0.05$. 
Table 6 Treatment level marginal means for the acoustic velocity measurements, obtained by the different tools for the different levels of final stand density and genetic rating treatments in the pruned and unpruned experiments

\begin{tabular}{|c|c|c|c|c|c|c|c|}
\hline \multirow[t]{2}{*}{ Factor } & \multirow{2}{*}{$\begin{array}{l}\text { Factor } \\
\text { level }\end{array}$} & \multicolumn{3}{|c|}{ Pruned experiment marginal mean $\left(\mathrm{km} \mathrm{s}^{-1}\right)$} & \multicolumn{3}{|c|}{ Unpruned experiment marginal mean $\left(\mathrm{km} \mathrm{s}^{-1}\right)$} \\
\hline & & ST-300 & IML hammer & HM-200 & ST-300 & IML hammer & HM-200 \\
\hline \multirow[t]{5}{*}{ Final stand density $\left(\right.$ stems ha ${ }^{-1}$ ) } & 100 & $2.447^{\mathrm{a}}(0.013)$ & $1.901^{\mathrm{a}}(0.002)$ & $1.883^{\mathrm{a}}(0.035)$ & - & - & - \\
\hline & 200 & $2.749^{b}(0.006)$ & $2.097^{\mathrm{b}}(0.003)$ & $2.089^{b}(0.008)$ & $2.600^{\mathrm{a}}(0.024)$ & $1.928^{\mathrm{a}}(0.038)$ & $2.001^{\mathrm{a}}(0.007)$ \\
\hline & 400 & $3.097^{\complement}(0.028)$ & $2.336^{\mathrm{C}}(0.020)$ & $2.365^{\complement}(0.020)$ & $2.959^{\mathrm{b}}(0.004)$ & $2.155^{\mathrm{a}}(0.031)$ & $2.280^{b}(0.026)$ \\
\hline & 600 & - & - & - & $2.857^{\mathrm{b}}(0.050)$ & $2.129^{\mathrm{a}}(0.054)$ & $2.293^{b}(0.071)$ \\
\hline & 1000 & - & - & - & $2.831^{b}(0.001)$ & $2.118^{\mathrm{a}}(0.013)$ & $2.341^{b}(0.009)$ \\
\hline \multirow[t]{2}{*}{ Genetic rating } & GF6 & $2.748^{5}(0.183)$ & $2.104^{5}(0.119)$ & $2.097^{5}(0.144)$ & $2.820^{5}(0.085)$ & $2.097^{5}(0.070)$ & $2.252^{5}(0.075)$ \\
\hline & GF25 & $2.780^{5}(0.192)$ & $2.118^{\mathrm{s}}(0.132)$ & $2.128^{5}(0.137)$ & $2.804^{\mathrm{s}}(0.068)$ & $2.067^{5}(0.035)$ & $2.205^{5}(0.075)$ \\
\hline
\end{tabular}

Note: The standard error of each mean is given in parentheses below each mean. Means in the same column, for a given factor, indicated by the same letter a, $b$, or $\mathrm{c}$ (for the stocking factor) and $\mathrm{s}$ and $\mathrm{t}$ (for the genetic rating factor) are not significantly different from each other at $p=0.05$ using the Tukey honest significant difference $p$-value adjustment for multiple comparisons to maintain an experiment-wise error $p$-value of 0.05 .

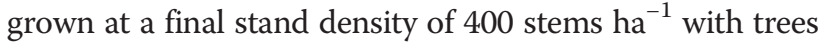
from both seedlots exhibiting a faster radial rate of decline in MFA at higher final stand densities (Figure 5a).

In the unpruned experiment, pith-ring MFA (parameter $\left.\alpha_{i j}\right)$ was significantly higher $(p<0.05)$ in GF6-rated trees grown at a final stand density of 400 stems ha $^{-1}$ compared with those grown at 200 stems ha $^{-1}$ (Figure 5b) but there were no significant differences at higher final stand densities. For the GF25-rated seedlot, pith-ring MFA in trees grown at a final stand density of 1000 stems $\mathrm{ha}^{-1}$ was significantly lower than those grown at final stand densities of 200, 400 or 600 stems ha ${ }^{-1}$. The trend

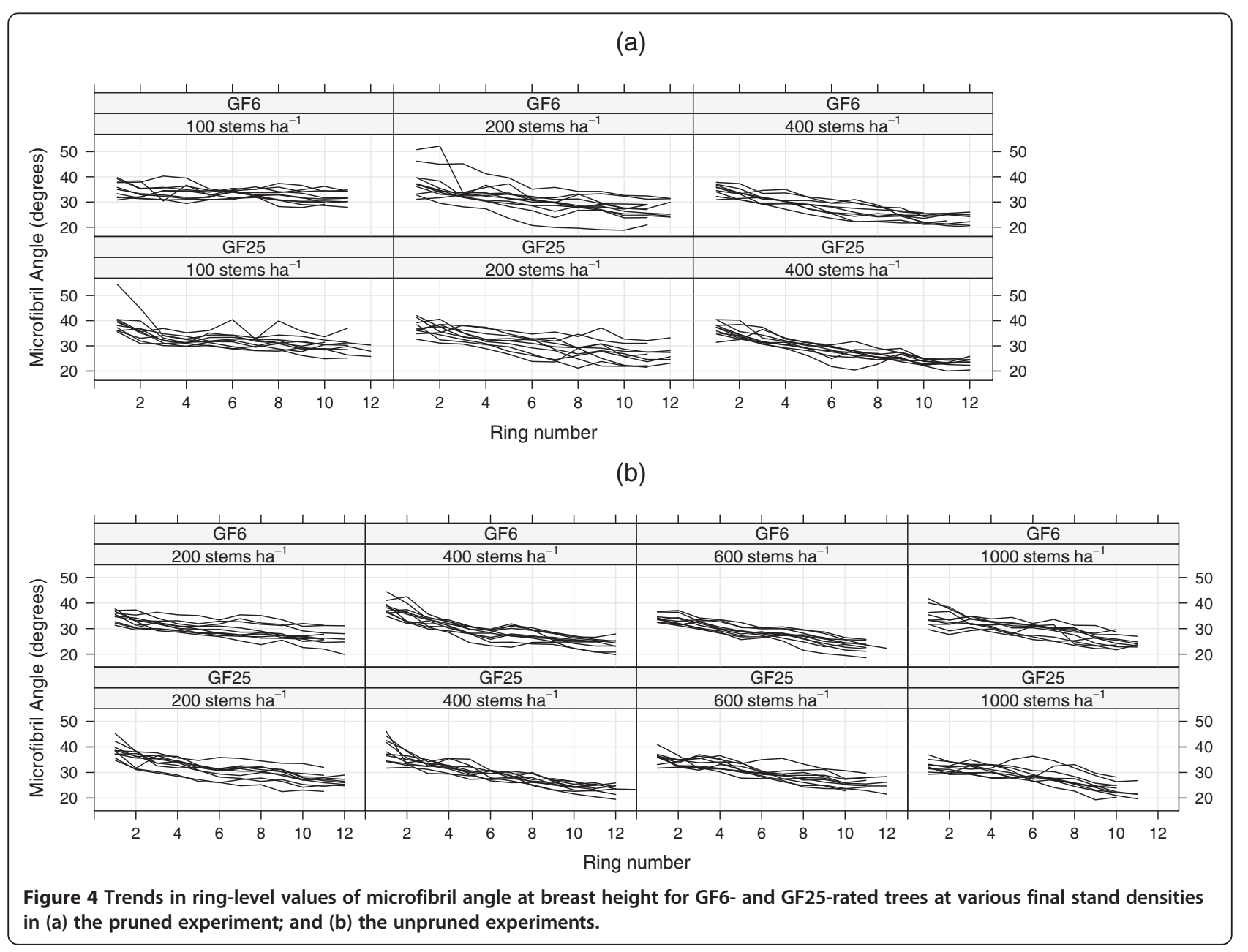




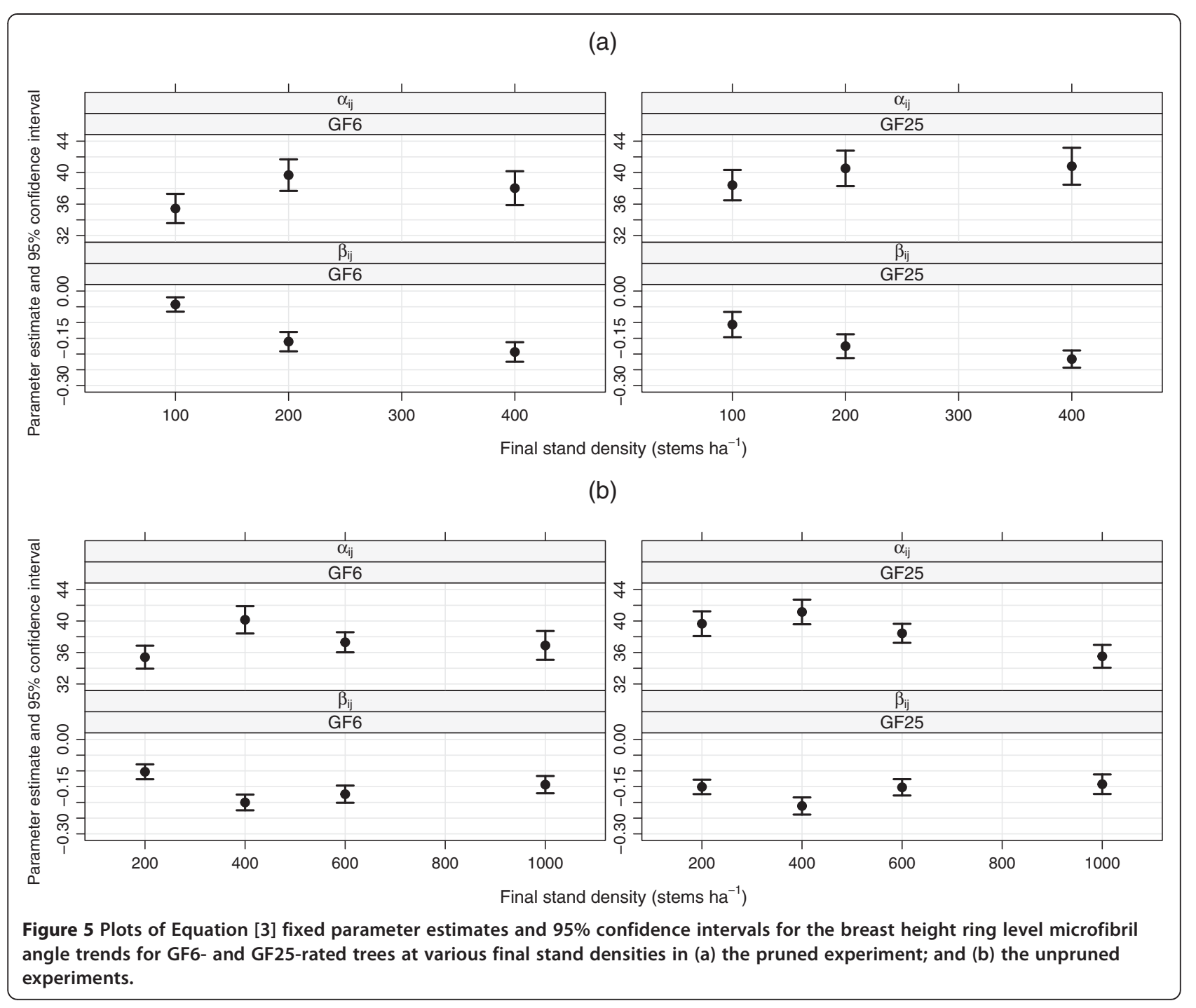

in radial rate of decrease in MFA with final stand density in the unpruned experiment differed from that observed in the pruned experiment. Except for the faster radial rate of decrease in MFA at a stand density 400 stems $\mathrm{ha}^{-1}$, there was essentially no change in rate of decline in MFA with change in stand density for trees from the GF25-rated seedlot (Figure 5b). In trees from the GF6-rated seedlot, the radial rate of decrease in MFA at a stand density of 400 stems $^{-1}$ was significantly higher than at a stand density of 200 stems ha ${ }^{-1}$. However, the rate of decrease at stand densities of 600 and 1000 stems ha $^{-1}$ did not differ from that observed at 400 stems ha $^{-1}$.

Overall, there was no difference in predicted MFA for ring 15 from the pith between the GF6- and GF25-rated seedlots (Table 7). However predicted MFA differed with stand density, and was $8^{\circ}$ higher in pruned trees growing at 100 stems ha ${ }^{-1}$ than in pruned trees growing at 400 stems $\mathrm{ha}^{-1}$. In the unpruned experiment, there was no change in MFA with further increases in stand density above a value of 400 stems ha $^{-1}$ (Table 7).

\section{Ring-level modulus of elasticity}

In the pruned experiment, pith-ring $\mathrm{MOE}$ (parameter $\alpha_{i j}$ ) in the GF25-rated seedlot trees was significantly lower than in GF6-rated seedlot trees (at $p=0.05$ ) at final stand densities of 100 and 400 stems ha $^{-1}$ (Figure 6a). There was no significant effect of final stand density on pith-ring MOE in the GF6-rated seedlot trees but a small reduction for GF25-rated seedlot trees. The estimated radial rate of change (parameter $\beta_{i j}$ ) was positive in all cases indicating that breast-height MOE for trees in the pruned experiment increased with increasing ring number from the pith. For both seedlots, there was a positive correlation between rate of radial increase in breast-height ringlevel MOE and final stand density. Overall, MOE in ring 15 from the pith was twice as high in trees grown 
Table 7 Treatment level marginal means for predicted values of wood density, MFA and MOE for ring 15 from the pith for the different levels of final stand density and genetic rating treatments in the pruned and unpruned experiments

\begin{tabular}{|c|c|c|c|c|c|c|c|}
\hline \multirow[t]{2}{*}{ Factor } & \multirow{2}{*}{$\begin{array}{l}\text { Factor } \\
\text { level }\end{array}$} & \multicolumn{3}{|c|}{ Pruned experiment marginal mean } & \multicolumn{3}{|c|}{ Unpruned experiment marginal mean } \\
\hline & & Density $\left(\mathrm{kg} \mathrm{m}^{-3}\right)$ & MFA $\left({ }^{\circ}\right)$ & MOE (kN mm-2) & Density $\left(\mathrm{kg} \mathrm{m}^{-3}\right)$ & $\operatorname{MFA}\left({ }^{\circ}\right)$ & MOE (kN mm-2 \\
\hline \multirow[t]{5}{*}{ Final stand density $\left(\right.$ stems ha ${ }^{-1}$ ) } & 100 & $465^{a}(9.2)$ & $30^{a}(0.8)$ & $5.39^{a}(0.23)$ & - & - & - \\
\hline & 200 & $455^{\mathrm{a}}(9.2)$ & $25^{\mathrm{b}}(0.8)$ & $8.11^{\mathrm{b}}(0.23)$ & $445^{\mathrm{a}}(4.6)$ & $27^{\mathrm{a}}(0.7)$ & $7.54^{\mathrm{a}}(0.55)$ \\
\hline & 400 & $483^{\mathrm{a}}(9.2)$ & $22^{\mathrm{b}}(0.8)$ & $10.66^{\mathrm{C}}(0.23)$ & $459^{\mathrm{ab}}(4.6)$ & $23^{b}(0.7)$ & $10.28^{\mathrm{b}}(0.55)$ \\
\hline & 600 & - & - & - & $470^{b}(4.6)$ & $24^{\mathrm{b}}(0.7)$ & $10.26^{\mathrm{b}}(0.55)$ \\
\hline & 1000 & - & - & - & $470^{b}(4.6)$ & $25^{\mathrm{ab}}(0.7)$ & $9.98^{b}(0.55)$ \\
\hline \multirow[t]{2}{*}{ Genetic rating } & GF6 & $485^{5}(7.5)$ & $26^{5}(0.6)$ & $8.04^{5}(0.18)$ & $478^{5}(3.3)$ & $25^{5}(0.5)$ & $9.72^{5}(0.39)$ \\
\hline & GF25 & $451^{\mathrm{t}}(7.5)$ & $27^{5}(0.6)$ & $8.07^{5}(0.18)$ & $444^{t}(3.3)$ & $25^{5}(0.5)$ & $9.29^{5}(0.39)$ \\
\hline
\end{tabular}

See notes from Table 6 for assistance in interpreting this table.

at a final stand density of 400 stems $\mathrm{ha}^{-1}$ than those grown at 100 stems $\mathrm{ha}^{-1}$ irrespective of seedlot (Table 7).

In the unpruned experiment, generally only small differences were observed in either pith-ring MOE (parameter $\alpha_{i j}$ ) or radial rate of change (parameter $\beta_{i j}$ ) between seedlots and among final stand densities (Figure $6 \mathrm{~b}$ ). The exception was at a final stand density of 200 stems ha ${ }^{-1}$, where pith-ring MOE for trees from the GF25-rated seedlot was lower than those from the GF6-rated seedlot,

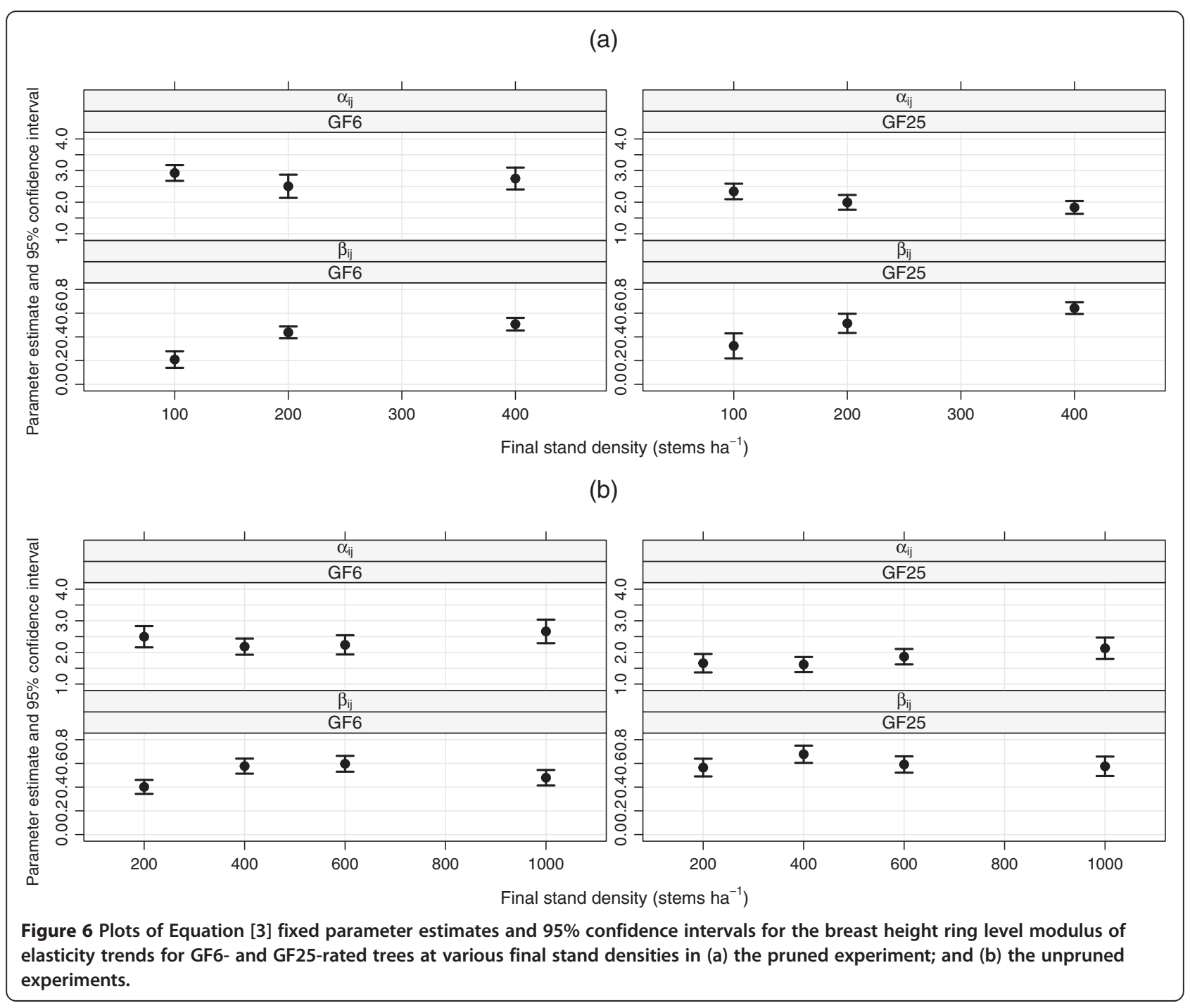


and the rate of radial increase in MOE for GF25-rated seedlot trees was faster than for GF6 seedlot trees. The optimal final stand density for MOE in ring 15 from the pith was 400 stems ha $^{-1}$ irrespective of seedlot.

\section{Ring-level wood density}

Some differences in ring-level wood density between seedlots were observed in both the pruned and unpruned experiments. There were some differences in pith-ring wood density (parameter $\alpha_{i j}$ ) between trees from the GF6- and GF25-rated seedlots, but generally no differences across final stand densities for trees from a given seedlot. In the pruned experiment, pith-ring wood density in trees from the GF25-rated seedlot trees growing at a final stand density of 400 stems ha ${ }^{-1}$ was significantly lower than equivalent GF6-rated seedlot trees (Figure 7a). A similar trend was observed for trees grown at a final stand density of 1000 stems ha ${ }^{-1}$ in the unpruned experiment (Figure 7b).
The rate of radial increase in wood density (parameter $\beta_{i j}$ ) did not change with final stand density for the GF6rated seedlot in either experiment, but was higher at greater stand densities for the GF25-rated seedlot in the pruned experiment (Figure 7a). However, no significant differences (at $p=0.05$ ) were observed in the rate of radial increase in ring-level wood density with changes in stand density in the unpruned experiment (Figure 7b). Overall, the predicted value of wood density in ring 15 was $34 \mathrm{~kg} \mathrm{~m}^{-3}$ lower for GF25-rated seedlot trees than those from the GF6-rated seedlot (Table 7). In the unpruned experiment, wood density for ring 15 was $24 \mathrm{~kg} \mathrm{~m}^{-3}$ higher for trees grown at a final stand density of 1000 stems ha $^{-1}$ compared with 200 stems ha ${ }^{-1}$.

\section{Discussion}

The direct positive correlation between MOE and final stand density was consistent with observations from other studies on radiata pine (Lasserre et al. 2005; Lasserre

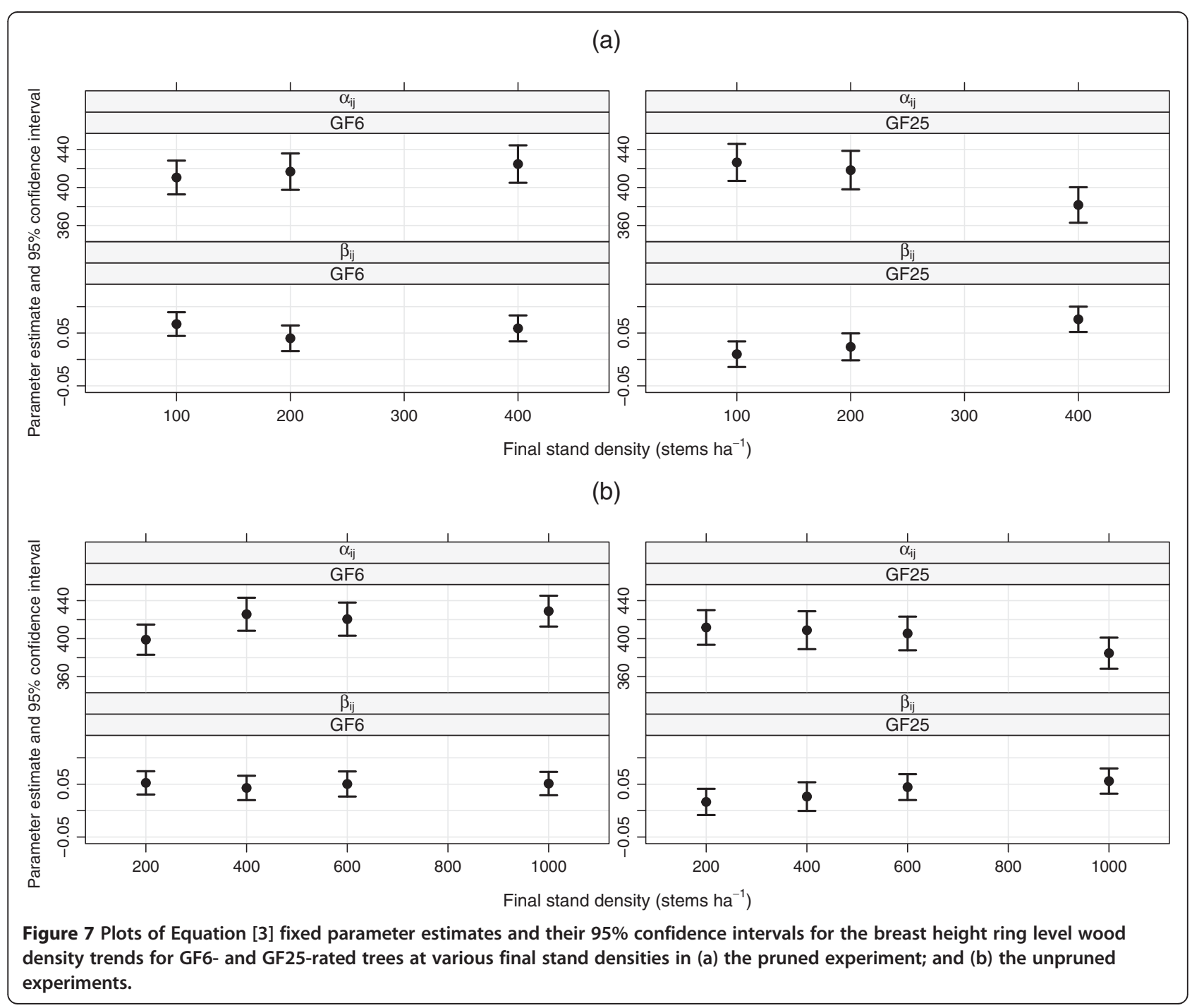


et al. 2008; Lasserre et al. 2009; Raymond et al. 2008; Waghorn et al. 2007; Watt et al. 2011) and a range of different species (Brazier and Mobbs 1993; Chuang and Wang 2001; Clark III et al. 2008; Moore et al. 2009; Roth et al. 2007; Wang and Ko 1998; Wang et al. 2005; Zhang et al. 2002; Zhang et al. 2006). The smallest MOE values occurred when final stand density was below 400 stems $\mathrm{ha}^{-1}$, with higher MOE values occurring at higher final stand densities. A similar effect was observed in a nearby Nelder-spacing experiment with radiata pine. Outerwood MOE was $5.4 \mathrm{kN} \mathrm{mm}^{-2}$ in trees grown at a stand density of 209 stems ha ${ }^{-1}$ compared with $6.6 \mathrm{kN} \mathrm{mm}^{-2}$ for trees at a stand density of 489 stems $\mathrm{ha}^{-1}$. This latter value of MOE was not significantly different from that for trees grown at a stand density of 2551 stems ha ${ }^{-1}$ (Waghorn et al. 2007).

In this study wood density differences were mostly related to differences between the two seedlots examined rather than to differences in final stand density. This result is in contrast to several previous studies in radiata pine that have found a significant effect of stand density on wood density (Cown 1973, 1974; Grace and Evans 2012; Watt et al. 2011), but consistent with others that have shown little or no effect (Lasserre et al. 2009; Sutton and Harris 1974). In 24-year-old radiata pine stands, Watt et al. (2011) observed a $92 \mathrm{~kg} \mathrm{~m}^{-3}$ increase in wood density over a similar range of stand densities to those examined in this study (i.e. 200 stems ha $^{-1}$ up to 1100 stems $\mathrm{ha}^{-1}$ ). There was a large amount of tree-to-tree variation observed in the radial profiles of wood density in the current study as well as a number of distinct annual shifts (Figure 2), which meant that only around $18 \%$ of the variation in wood density could be explained using the fixed effects included in the model tested. It is possible that these shifts in density between years, particularly the one observed in 2002 (i.e. at ring 10), were due to climatic factors as similar responses were observed across trees from both seedlots and at all final stand densities. In a study on loblolly pine (Pinus taeda L.) Cregg et al. (1988) observed that climatic signals had more influence on wood density than thinning treatments. Final stand density (irrespective of thinning) can still have an effect on average stem or log density even if there is no effect on wood density on an equivalent annual-ring basis. This effect occurs because growing space affects radial growth. Thus, trees in thinned stands or those planted at a wide initial spacing will reach a target diameter in a shorter period of time than more densely planted stands. Consequently, they have a higher proportion of low density corewood and lower average density (Cown 1974).

Fewer studies examining the effect of stand density on MFA have been published than those investigating the effect on wood density. However, two such studies in radiata pine found that MFA was lower at higher initial stand densities (Lasserre et al. 2009; Watt et al. 2011). The study by Watt et al. (2011) was over a similar range of stand densities to those reported in this study (i.e. 200 stems ha ${ }^{-1}$ to 1100 stems $\mathrm{ha}^{-1}$ ), but the study by Lasserre et al. (2009) was in stands grown at 833 stems ha $^{-1}$ up to 2500 stems ha $^{-1}$. In a separate study, Downes et al. (2002) found that thinning (combined with fertilisation) resulted in larger MFA values for radiata pine. Several studies in other species have also found a positive relationship between growth rate and MFA, i.e. faster growth rates are associated with higher MFA (Auty et al. 2013; Herman et al. 1999; Lindström et al. 1998). Therefore, it was somewhat unexpected that the largest difference in MFA observed in the current study occurred between trees grown in stands with final densities of 100 stems ha ${ }^{-1}$ and 400 stems ha ${ }^{-1}$, neither of which are considered high. It is also pertinent to note that the largest difference in DBH occurred between stand densities of 400 stems ha ${ }^{-1}$ and 1000 stems ha ${ }^{-1}$.

The almost $5^{\circ}$ improvement in MFA and $>2 \mathrm{kN} \mathrm{mm}^{-2}$ reduction in MOE between final stand densities of 400 stems $\mathrm{ha}^{-1}$ and 200 stems $\mathrm{ha}^{-1}$ respectively are highly significant from a wood utilisation perspective (Moore 2012; Walker and Butterfield 1995). The two MOE values are different enough to represent a change of one grade in the New Zealand machine-strength grading system, which could have a substantial impact for a sawmill producing structural lumber. The results presented here indicate that it is not necessary to maintain extremely high stand densities in order to have good wood quality in radiata pine. Also, early thinning has a number of other benefits as it will result in lower mortality later in the rotation and also produces larger diameter logs that generally have higher value (Smith et al. 1997). Another important finding was that the GF25-rated seedlot used for this trial produced trees with a lower wood density and MOE compared with those from the GF6-rated seedlot. These results indicate that, in some cases, past gains in growth and form have come at the expense of wood quality. This phenomenon is well recognised by tree breeders who have focussed on improving the wood density of radiata pine for some time (Jayawickrama and Carson 2000). More recently, improvements in the wood stiffness of radiata pine have also been sought (Dungey et al. 2006; Kumar et al. 2006).

The Shellocks trial is part of a much larger trial series, which has installations across different site qualities within New Zealand. These trials will reach maturity in the next 5-8 years, which will enable researchers to determine whether the trends observed here also hold at other sites and in mature trees where the contrast in levels of competition between spacing treatments is expected to be more marked. Results from an earlier 
24-year-old thinning trial where the treatments had been applied at age 5 years indicate that differences in properties could be expected to increase with increasing stand age (Watt et al. 2011). The experimental design for the national trial series also enables the site by silviculture and site by seedlot interactions to be investigated. The earlier installations in this trial series have two replicates of each combination of seedlot and final stand density, which will allow the interaction between these factors to also be tested. However, two previous studies that have examined this interaction have found that it was not significant (Lasserre et al. 2009; Waghorn et al. 2007).

\section{Conclusion}

The results obtained in this study indicate, for this site at least, that early thinning down to a final stand density of 400 stems $\mathrm{ha}^{-1}$ had no detrimental effect on wood stiffness. However, there are substantial adverse impacts on wood MFA and MOE at final stand densities below this level. Thus, forest managers are able to influence the wood properties of radiata pine trees through manipulating stand density. The greatest change in wood properties occurred over a range of final stand densities where there was a significant change in tree height, but only a modest change in tree diameter. With the exception of wood density, tree spacing had a much stronger effect on wood properties than differences in seedlot. This result indicates that extremely high stand densities are not necessary in order to improve wood properties, but thinning to low residual stand densities should be avoided. Assessing the remaining trials in this series will enable the conclusions obtained from this trial to be validated across a wider range of sites and in mature trees.

\section{Competing interests}

The authors declare that they have no competing interests.

\section{Authors' contributions}

JRM was assisted with planning the study, field data collection, data analysis and writing of the manuscript. DJC and RBMcK planned the study, undertook field and laboratory analyses and assisted with the interpretation of the results. COS analysed the data and assisted with writing the manuscript. All authors read and approved the final version of the manuscript.

\section{Acknowledgements}

The authors wish to thank WQI Ltd for funding the study and giving permission to publish the results. Don McConchie, Marco Lausberg and Craig Treloar assisted with the field work. Funding to support the additional analysis and publication of the results was provided by Future Forests Research Ltd. Drs Ruth Falshaw and Ruth Gadgil provided numerous helpful comments on an earlier version of the manuscript.

\section{Author details}

'Scion, Private Bag 3020, Rotorua 3046, New Zealand. ${ }^{2}$ Present address: Department of Forestry, Mississippi State University, P.O. Box 9681, Mississippi State, MS 39762, USA.

Received: 16 October 2014 Accepted: 15 March 2015

Published online: 18 April 2015

\section{References}

Assmann, E. (1970). The Principles of Forest Yield Study. New York: Pergamon Press.

Auty, D, Gardiner, BA, Achim, A, Moore, JR, \& Cameron, AD. (2013). Models for predicting microfibril angle variation in Scots pine. Annals of Forest Science, 70, 209-218. doi:10.1007/s13595-012-0248-6.

Auty, D, Weiskittel, AR, Achim, A, Moore, JR, \& Gardiner, BA. (2012). Influence of early re-spacing on Sitka spruce branch structure. Annals of Forest Science, 69, 93-104. doi:10.1007/s13595-011-0141-8.

Brazier, JD, \& Mobbs, ID. (1993). The influence of planting distance on structural wood yields of unthinned Sitka spruce. Forestry, 66, 333-352.

Burdon, RD. (2008). Branching habit in radiata pine - breeding goals revisited. New Zealand Journal of Forestry, 52(4), 20-23.

Burdon, RD, Kibblewhite, RP, Walker, JCF, Megraw, RA, Evans, R, \& Cown, DJ. (2004). Juvenile versus mature wood: a new concept, orthogonal to corewood versus outerwood, with special reference to Pinus radiata and P. taeda. Forest Science, 50(4), 399-415.

Carson, SD. (1996). Greater specialisation of improved seedlots in New Zealand: New developments for efficient selection of parents and evaluation of performance. New Zealand Journal of Forestry, 41(1), 12-17.

Carson, SD, Kimberley, MO, Hayes, JD, \& Carson, MJ. (1999). The effect of silviculture on genetic gain in growth of Pinus radiata at one-third rotation. Canadian Journal of Forest Research, 29(12), 1979-1984. doi:10.1139/x99-152.

Chuang, ST, \& Wang, SY. (2001). Evaluation of standing tree quality of Japanese cedar grown with different spacing using stress wave and ultrasonic-wave methods. Journal of Wood Science, 47, 245-253.

Clark III, A, Jordan, L, Schimleck, L, \& Daniels, RF. (2008). Effect of initial planting spacing on wood properties of unthinned loblolly pine at age 21. Forest Products Journal, 58(10), 78-83.

Cown, DJ. (1973). Effects of severe thinning and pruning treatments on the intrinsic wood properties of young radiata pine. New Zealand Journal of Forestry Science, 3, 379-389.

Cown, DJ. (1974). Comparison of the effects of two thinning regimes on some wood properties of radiata pine. New Zealand Journal of Forestry Science, 4, 540-551

Cregg, BM, Dougherty, PM, \& Hennessey, TC. (1988). Growth and wood quality factors in relation to stand density and climatic factors. Canadian Journal of Forest Research, 18, 851-858.

Downes, GM, Nyakuengama, JG, Evans, R, Northway, R, Blakemore, P, Dickson, RL, \& Lausberg, M. (2002). Relationship between wood density, microfibril angle and stiffness in thinned and fertlized Pinus radiata. IAWA Journal, 23(3), 253-265.

Dungey, HS, Matheson, AC, Kain, D, \& Evans, R. (2006). Genetics of wood stiffness and its component traits in Pinus radiata. Canadian Journal of Forest Research, 36(5), 1165-1178.

Evans, R. (1999). A variance approach to the X-ray diffractometric estimation of microfibril angle in wood. Appita Journal, 52(4), 283-289. 294.

Evans, R, Hughes, M, \& Menz, D. (1999). Microfibril angle variation by scanning X-ray diffractometry. Appita Journal, 52(5), 363-367.

Evans, R, \& llic, J. (2001). Rapid prediction of wood stiffness from microfibril angle and density. Forest Products Journal, 51(3), 53-57.

Evert, F. (1971). Spacing Studies: A Review. Information Report FMR-X-37. Ottawa: Canadian Forest Service, Forest Management Institute.

Fenton, RT, \& Sutton, WRJ. (1968). Silvicultural proposals for radiata pine on high quality sites. New Zealand Journal of Forestry, 13, 220-228.

Gapare, WJ, Baltunis, BS, Ivković, M, \& Wu, HX. (2009). Genetic correlations among juvenile wood quality and growth traits and implications for selection strategy in Pinus radiata D. Don. Annals of Forest Science, 66(6), 606-606. doi:10.1051/forest/2009044.

Grace, JC, \& Evans, R. (2012). Impact of thinning and pruning on selected wood properties in individual radiata pine trees in New Zealand. New Zealand Journal of Forestry Science, 42, 117-129.

Hein, S, Weiskittel, AR, \& Kohnle, U. (2008). Effect of wide spacing on tree growth, branch and sapwood properties of young Douglas-fir [Pseudotsuga menziesii (Mirb.) Franco] in south-western Germany. European Journal of Forest Research, 127, 481-493.

Herman, M, Dutilleul, P, \& Avella-Shaw, T. (1999). Growth rate effects on intra-ring and inter-ring trajectories of microfibril angle in Norway spruce (Picea abies). IAWA Journal, 20(1), 3-21.

Hewitt, AE. (1998). New Zealand Soil Classification (2nd ed.). Lincoln: Landcare Research Science Series. 
James, RN. (1990). Evolution of Silvicultural Practice Towards Wide Spacing and Heavy Thinnings In New Zealand. In RN James \& GL Tarlton (Eds.), New Approaches to Spacing and Thinning in Plantation Forestry. FRI Bulletin 151 (pp. 13-20). Rotorua, New Zealand Ministry of Forestry, Forest Research Institute.

Jayawickrama, KJS, \& Carson, MJ. (2000). A breeding strategy for the New Zealand Radiata Pine Breeding Cooperative. Silvae Genetica, 49(2), 82-90.

Jayawickrama, KJS, Shelbourne, CJA, \& Carson, MJ. (1997). New Zealand's long internode breed of Pinus radiata. New Zealand Journal of Forestry Science, 27, 126-141.

Kilpatrick, DJ, Sanderson, JM, \& Savill, PS. (1981). The influence of five early respacing treatments on the growth of Sitka spruce. Forestry, 54(1), 17-29.

Kumar, S. (2004). Genetic parameter estimates for wood stiffness, strength, internal checking, and resin bleeding for radiata pine. Canadian Journal of Forest Research, 34(12), 2601-2610.

Kumar, S, \& Burdon, RD. (2010). Genetic improvement of stiffness of radiata pine: synthesis of results from acoustic assessments. New Zealand Journal of Forestry Science, 40, 185-197.

Kumar, S, Burdon, RD, Stovold, GT, \& Gea, LD. (2008). Implications of selection history on genetic architecture of growth, form, and wood-quality traits in Pinus radiata. Canadian Journal of Forest Research, 38(9), 2372-2381.

Kumar, S, Dungey, HS, \& Matheson, AC. (2006). Genetic parameters and strategies for genetic improvement of stiffness in radiata pine. Silvae Genetica, 55(2), 77-84.

Lasserre, J-P, Mason, EG, \& Watt, MS. (2005). The effects of genotype and spacing on Pinus radiata [D. Don] corewood stiffness in an 11-year old experiment. Forest Ecology and Management, 205(1-3), 375-383. doi:10.1016/j.foreco.2004.10.037.

Lasserre, JP, Mason, EG, \& Watt, MS. (2008). Influence of the main and interactive effects of site, stand stocking and clone on Pinus radiata $D$. Don corewood modulus of elasticity. Forest Ecology and Management, 255(8-9), 3455-3459.

Lasserre, JP, Mason, EG, Watt, MS, \& Moore, JR. (2009). Influence of initial planting spacing and genotype on microfibril angle, wood density, fibre properties and modulus of elasticity in Pinus radiata D. Don corewood. Forest Ecology and Management, 258(9), 1924-1931. doi:10.1016/j.foreco.2009.07.028.

Lindström, H, Evans, JW, \& Verrill, SP. (1998). Influence of cambial age and growth conditions on microfibril angle in young Norway spruce (Picea abies [L.] Karst.). Holzforschung, 52(6), 573-581.

Macdonald, E, \& Hubert, J. (2002). A review of the effects of silviculture on timber quality of Sitka spruce. Forestry, 75(2), 107-137.

Maguire, DA, Kershaw, JA, Jr, \& Hann, DW. (1991). Predicting the effects of silvicultural regime on branch size and crown wood core in Douglas-fir. Forest Science, 37, 1409-1428.

Milliken, GA, \& Johnson, DE (1989). Analysis of messy data: nonreplicated experiments (Vol. 2) Boca Raton, FL: CRC Press.

Ministry for Primary Industries. (2012). National Exotic Forest Description as at 1 April 2012. Wellington, New Zealand: Ministry for Primary Industries.

Moore, J. (2012). Growing fit-for-purpose structural timber: what is the target and how do we get there? New Zealand Journal of Forestry, 57(3), 17-24.

Moore, J, Achim, A, Lyon, A, Mochan, S, \& Gardiner, B. (2009). Effects of early re-spacing on the physical and mechanical properties of Sitka spruce structural timber. Forest Ecology and Management, 258(7), 1174-1180.

New Zealand Meteorological Service. (1983). Summaries of Climate Observations To 1980. Wellington: New Zealand Meteorological Service Miscellaneous Publication 177

Panshin, AJ, \& de Zeeuw, C. (1980). Textbook of Wood Technology (4th ed.). New York: McGraw-Hill.

Pinheiro, JC, Bates, DM, DebRoy, S, Sarkar, D, \& R Development Core Team. (2013). nlme: Linear and Nonlinear Mixed Effects Models. R package version 3 (pp. 1-113).

R Development Core Team (2014). R: a language and environment for statistical computing. Vienna: R Foundation for Statistical Computing.

Raymond, CA, Joe, B, Anderson, DW, \& Watt, DJ. (2008). Effect of thinning on relationships between three measures of wood stiffness in Pinus radiata: Standing trees vs. logs vs. short clear specimens. Canadian Journal of Forest Research, 38(11), 2870-2879.

Roos, A, Woxblom, L, \& McCluskey, D. (2010). The influence of architects and structural engineers on timber in construction - perceptions and roles. Silva Fennica, 44, 871-884.

Roth, BE, Li, X, Huber, DA, \& Peter, GF. (2007). Effects of management intensity, genetics and planting density on wood stiffness in a plantation of juvenile loblolly pine in the southeastern USA. Forest Ecology and Management, 246(2-3), 155-162.
SAS Institute Inc. (2004-2009). SAS 9.2 Help and Documentation. Cary, NC: SAS Institute Inc.

Savill, PS, \& Sandels, AJ. (1983). The influence of early respacing on the wood density of Sitka spruce. Forestry, 65(2), 109-120.

Smith, DM, Larson, BC, Kelty, MJ, \& Ashton, PMS (1997). The practice of silviculture: applied forest ecology (Ninth ed.) New York: John Wiley \& Sons.

Sutton, WRJ, \& Harris, JM. (1974). Effect of heavy thinning on wood density in radiata pine. New Zealand Journal of Forestry Science, 4, 112-115.

Tukey, JW. (1949). One degree of freedom for non-additivity. Biometrics, 5(3), 232-242. doi:10.2307/3001938.

Vincent, TG. (1987). Certification System for Forest Tree Seed and Planting Stock. (FRI Bulletin 134). Rotorua: New Zealand Forest Research Institute.

Vinden, P. (2003). Changes in markets, technology and resources: prospects for wood-based products. Australian Forestry, 66, 51-54.

Waghorn, MJ, Watt, MS, \& Mason, EG. (2007). Influence of tree morphology, genetics, and initial stand density on outerwood modulus of elasticity of 17-year-old Pinus radiata. Forest Ecology and Management, 244(1-3), 86-92. doi:10.1016/j.foreco.2007.03.057.

Walker, JCF, \& Butterfield, B. (1995). The importance of microfibril angle for the processing industries. New Zealand Journal of Forestry, 40(4), 34-40.

Wang, S-Y, \& Ko, C-Y. (1998). Dynamic modulus of elasticity and bending properties of large beams of Taiwan-grown Japanese cedar from different plantation spacing sites. Journal of Wood Science, 44, 62-68.

Wang, S-Y, Lin, C-J, \& Chiu, C-M. (2005). Evaluation of wood quality of Taiwania trees grown with different thinning prunning treatments using ultrasonic-wave testing. Wood and Fiber Science, 37(2), 192-200.

Watson, AJ, Davie, TJA, Bowden, W, \& Payne, JJ. (2004). Drainage to groundwater under a closed-canopy radiata pine plantation on the Canterbury Plains, South Island, New Zealand. Journal of Hydrology (NZ), 43, 111-123.

Watt, MS, Whitehead, D, Richardson, B, Mason, EG, \& Leckie, AC. (2003). Modelling the influence of weed competition on the growth of young Pinus radiata at a dryland site. Forest Ecology and Management, 178, 271-286.

Watt, MS, Zoric, B, Kimberley, MO, \& Harrington, J. (2011). Influence of stocking on radial and longitudinal variation in modulus of elasticity, microfibril angle, and density in a 24-year-old Pinus radiata thinning trial. Canadian Journal of Forest Research, 41(7), 1422-1431. doi: 10.1139/x11-070.

Whyte, AGD, \& Woollons, RC. (1990). Modelling stand growth of radiata pine thinned to varying densities. Canadian Journal of Forest Research, 20, 1069-1076.

Zhang, SY, Chauret, G, Ren, QH, \& Desjardins, R. (2002). Impact of initial spacing on plantation black spruce lumber grade yield, bending properties, and MSR yield. Wood and Fiber Science, 34(4), 460-475.

Zhang, SY, Chauret, G, Swift, DE, \& Duchesne, I. (2006). Effects of precommercial thinning on tree growth and lumber quality in a jack pine stand in New Brunswick, Canada. Canadian Journal of Forest Research, 36(4), 945-952. doi:10.1139/x05-307.

Zobel, BJ, \& Jett, JB. (1995). Genetics of Wood Production. Berlin: Springer.

Zobel, BJ, \& Sprague, JR. (1998). Juvenile wood in forest trees. Berlin: Springer.

\section{Submit your manuscript to a SpringerOpen ${ }^{\oplus}$ journal and benefit from:}

- Convenient online submission

- Rigorous peer review

- Immediate publication on acceptance

- Open access: articles freely available online

- High visibility within the field

- Retaining the copyright to your article

Submit your next manuscript at springeropen.com 